\title{
Risk Factors for Premature Rupture of the Membranes
}

\author{
Lilin Turlina*, Faizatul Ummah, Sulistyowati \\ Fakultas IImu Kesehatan, Universitas Muhammadiyah Lamongan, Lamongan, Indonesia
}

The incidence of premature rupture of membranes (PRM) ranges from 8-10\% at term pregnancy and $1 \%$ in preterm pregnancy. The incidence of PRM at RSUD dr. Soegiri Lamongan in 2017 amounted to 16,43\%. The purpose of this study was to analyze risk factors of the occurrence of premature rupture membranes in RSUD Dr. SoegiriLamongan. The research used descriptive analytical method with cross sectional approach. The sample is 268 maternity mothers, divided into 134 mothers giving birth with PRM and 134 normal maternity mothers at Dr. Soegiri Lamongan on 2018. Sampling is done by simple random sampling. Data collection uses patient medical record and with multivariate multiple logistic regression analysis. The results showed that presentation abnormalities with a $p$ value of $0.045<0.05$ and CPD with a $p$ value of $0.002<0.05$. Based on the Odds Ratio (OR) values as follows: Maternal age OR 1,141, OR parity 0.933, OR fetal presentation 2,779, OR Twins 1,394, OR CPD 6. and OR Large infants 0.783.Meaning that there was a significant influence between fetal presentation and CPD on PRM.

Keywords: Risk factor, premature rupture of membranes.

\section{INTRODUCTION}

OPEN ACCESS ISSN 2548-2246 (online) ISSN 2442-9139 (print)

Edited by: lid Putri Zulaida

Reviewed by: Evi Wahyuntari

${ }^{*}$ Correspondence:

Lilin Turlina

turlinalmg@gmail.com

Received: 11 Pebruari 2020

Accepted: 15 Pebruari 2020

Published: 05 Oktober 2020

Citation:

Turlina L, FU and S (2020) Risk

Factors for Premature Rupture of the Membranes.

Midwiferia Jurnal Kebidanan. 6:2. doi: $10.21070 /$ midwiferia.v\%vi\%i.60
The success of maternal health efforts, including can be seen from the indicator of Maternal Mortality Rate (MMR). The decline in MMR in Indonesia occurred since 1991 to 2007, namely from 320 to 228. However, the IDHS in 2012 showed a significant increase in MMR to 359 maternal deaths per 100,000 live births. PRM again showed a decrease to 305 maternal deaths per 100,000 live births based on the results of the 2015 Intercensal Population Survey of Indonesia Ministry of Health (2017).

MMR in East Java tends to decline in the last three years, but in 2016 it has increased again. According to SUPAS in 2016, the target for MMR is 305 per 100,000 live births. In 2016, the MMR of East Java Province reached 91,000 per 100,000 live births. This figure has increased compared to 2015 which reached 89.6 per 100,000 live births Office (2017). In Lamongan district in 2016 the number of maternal deaths handled by health workers based on reports from Puskesmas received by the family health sub-department of Lamongan District Health Office was 11 people with a Maternal Mortality Rate (MMR) of 64 per 100,000 live births Office (2016).

Maternal mortality in East Java in 2016 was caused by bleeding of $24.72 \%$, preeclampsia / eclampsia by $30.90 \%$, infection by $4.87 \%$, heart disease $10.86 \%$ and others $28.65 \%$. Maternal mortality due to infection as much as $4.87 \%$, which is one of the factors causing infection, is early rupture of the fetus in maternity Office (2017).

The incidence of premature rupture of membranes ranges from $8-10 \%$ at term or quite months, whereas in preterm pregnancy occurs in $1 \%$ of pregnancies. At term pregnancy occurs $90 \%$ of births within 24 hours after the membranes rupture. At 28-34 weeks of gestation 50\% of births occur within 24 hours and at gestational age less than 26 weeks of labor occur one 
week Wiknjosastro (2014). Data obtained at RSUD dr. Soegiri Lamongan in 2017 there were 834 women giving birth, while women who had premature ruptured membranes were 137 (16.43\%) people.

The cause of PRM is still unknown and cannot be determined with certainty. Some reports mention factors that are closely related to PRM, Possible factors that are predisposing and risk factors for The incidence of premature rupture of membranes are: 1) infection; 2) incompetent cervix; 3) intrauterine pressure; 4) trauma; 5) location abnormalities; 6) polyhydramnios; 7) previous PRM history; 8) abnormalities or damage to the membranes; 9) multiple pregnancies; 10) socio-economic conditions and 11) other factors, namely: blood type, disproportion between fetal head and maternal pelvis, multigravidity, smoking, antepartum bleeding and nutritional deficiencies of copper or vitamin C Nugroho (2012).

The results of the study conducted by Budi R, et al Budi and Sari (2017) showed that the majority of PRM incidents in multiparous mothers were 245 (57.4\%) people, gestational age $\geq 37$ weeks as many as $343(80.3 \%)$ people, normal uterine enlargement as much as $410(96.1 \%)$ people and head presentations were $396(92.7 \%)$ people. Whereas the study conducted by Assefa $\mathrm{Ne}$, et. al Ne et al. (1929) found that the history of abortion, history of PRM, history of Caesarean section and abnormal vaginal discharge in pregnancy were positively associated with premature rupture of membranes.

Complications of premature rupture of membranes that most often occur in mothers giving birth are infections in labor, postpartum infection, prolonged labor, postpartum hemorrhage, increasing cases of Caesarean section and increasing maternal morbidity and mortality. Whereas the most common complications in the fetus are prematurity, umbilical cord reduction, hypoxia and asphyxia, fetal deformity syndrome and increasing perinatal morbidity and mortality Marni (2011).

Premature rupture of membranes are an important problem in obstetrics related to complications in both the mother and the baby born. So that health workers play an important role in enforcing the diagnosis and appropriate implementation. Early detection and recognizing several risk factors for premature rupture of membranes are needed both during pregnancy and during labor.

\section{RESEARCH METHODS}

This research uses descriptive analytic study with case control approach. The study was conducted at Dr. Soegiri Lamongan from January 2018 to December 2018. A total of 268 maternity mothers, consisting of 134 maternity mothers with premature rupture of membranes and 134 normal maternity mothers, were taken by simple random sampling.

The technique of collecting data with secondary data is utilizing the official documents of the RSUD Dr. Soegiri Lamongan in the form of a respondent's medical record file.

Processing data using Multivariate analysis with Multiple Logistic Regression.

\section{RESULTS AND DISCUSSION}

\section{Research result}


TABLE 1 | Frequency Distribution of Risk Factors for Premature Rupture of Membranes at Dr. Soegiri Lamongan in 2018

\begin{tabular}{|c|c|c|c|c|c|c|}
\hline \multirow{2}{*}{ Variable } & \multicolumn{2}{|c|}{ Case } & \multicolumn{2}{|c|}{ Control } & \multicolumn{2}{|l|}{ Total } \\
\hline & f & $\%$ & f & $\%$ & f & $\%$ \\
\hline \multicolumn{7}{|l|}{ Age } \\
\hline Age $<20$ Years & 10 & $7.5 \%$ & 13 & $9.7 \%$ & 23 & $8.6 \%$ \\
\hline Age 20 - 35 Years & 98 & $73.1 \%$ & 101 & $75.4 \%$ & 199 & $74.2 \%$ \\
\hline Age $>35$ Years & 26 & $19.4 \%$ & 20 & $14.9 \%$ & 46 & $17.2 \%$ \\
\hline \multicolumn{7}{|l|}{ Parity } \\
\hline Primipara & 46 & $34.3 \%$ & 45 & $33.6 \%$ & 91 & $34 \%$ \\
\hline Multipara & 77 & $57.5 \%$ & 78 & $58.2 \%$ & 155 & $57.8 \%$ \\
\hline Grandemultipara & 11 & $8.2 \%$ & 11 & $8.2 \%$ & 22 & $8.2 \%$ \\
\hline \multicolumn{7}{|l|}{ Presentation } \\
\hline Behind the head & 117 & $87.3 \%$ & 128 & $95.5 \%$ & 245 & $91.4 \%$ \\
\hline Not behind te head & 17 & $12.7 \%$ & 6 & $4.5 \%$ & 23 & $8.6 \%$ \\
\hline \multicolumn{7}{|l|}{ Fetal amount } \\
\hline Single & 132 & $98.5 \%$ & 134 & $100 \%$ & 266 & 99.3 \\
\hline Double & 2 & $1.5 \%$ & 0 & $0 \%$ & 2 & $0.7 \%$ \\
\hline \multicolumn{7}{|l|}{ CPD } \\
\hline Yes & 22 & $16.4 \%$ & 4 & $3 \%$ & 26 & $9.7 \%$ \\
\hline No & 112 & $83.6 \%$ & 130 & $97 \%$ & 242 & $90.3 \%$ \\
\hline \multicolumn{7}{|l|}{ baby's weight } \\
\hline$<2500$ gram & 33 & $24.6 \%$ & 28 & $20.9 \%$ & 61 & $22.8 \%$ \\
\hline 2500 gram - 4000 gram & 80 & $59.7 \%$ & 93 & $69.4 \%$ & 173 & $64.5 \%$ \\
\hline$>4000$ gram & 21 & $15.7 \%$ & 13 & $9.7 \%$ & 34 & $12.7 \%$ \\
\hline
\end{tabular}

Tabel 1 above shows that the age of the mother in both the case group and the control group was mostly $(73.1 \%)$ and $(75.4 \%)$ aged between $20-35$ years. Data for maternal parity in both the case and control groups were mostly (57.5\%) and (58.2\%) were multiparous parity. Data for fetal presentation in both the case group and the control group were almost entirely $(87.3 \%)$ and (95.5\%) were back head presentations. Data for the total number of fetuses in the case group was almost entirely (98.5\%) were single pregnancies, whereas in the control group as a whole $(100 \%)$ was a single pregnancy. Data for the incidence of cephalo pelvic disproportion (CPD) in both the case group and the control group were almost entirely $(83.6 \%)$ and (97\%) were not experiencing CPD. And data for the weight of babies born both in the case group and the control group were mostly (59.7\%) and (69.4\%) were normal body weight between 2500 grams - 4000 grams. 
TABLE 2 | Analysis of Risk Factors for remature Rupture of Membranes at Dr. Soegiri Lamongan in 2018

\begin{tabular}{|c|c|c|c|c|c|c|c|c|}
\hline \multirow[t]{7}{*}{ Variabel } & & & S.E. & Wald & Sig. & $\operatorname{Exp}(B)$ & \multicolumn{2}{|c|}{$\begin{array}{l}\text { 95\% C.I.for } \\
\operatorname{Exp}(B)\end{array}$} \\
\hline & & & & & & & Lower & Upper \\
\hline & Age & .132 & .173 & .583 & .445 & 1.141 & .813 & 1.600 \\
\hline & Parity & -.070 & .220 & .099 & .753 & .933 & .606 & 1.437 \\
\hline & Fetal amount & 21.056 & 27724.314 & .000 & .999 & 1.394E9 & .000 & \\
\hline & CPD & 1.825 & .594 & 9.433 & .002 & 6.201 & 1.935 & 19.870 \\
\hline & Baby's weight & .055 & .200 & .076 & .783 & 1.057 & .714 & 1.564 \\
\hline
\end{tabular}


FromTabel 2 above, it can be seen that there are two independent variables which value $\mathrm{p}$ $<0.05$, which is fetal presentation variable with $p$ value of $0.045<0.05$ and CPD variable with $\mathrm{p}$ value of $0.002<0.05$, meaning that there is a significant influence between fetal presentation and CPD on PRM. While for the variables of age, parity, number of fetuses and weight infants did not significantly influence the incidence of PRM due to the value of $p>0.05$.

The results of multivariate analysis revealed that the Odds Ratio (OR) value was as follows: 1) Age 20-35 years had a risk of 1,141 times greater occurrence of PRM;2) Multiparous and grande multipara parities have a risk of 0.933 times greater experience of PRM; 3) Non-head presentation has a risk of 2,779 times greater experience of PRM. 4) Twin pregnancies have a greater risk of 1,394 experiencing PRM; 5) CPD has a greater risk of 6,201 experiencing PRM; and 6) Large infants (macrosomia) have a risk of 0.783 greater experience of PRM.

\section{Discussion Age Relationship with premature rupture of membranes}

Based on the research conducted, the majority of maternal age in both the case group and the control group (74.2\%) were aged between 201-35. Where the age includes the age of low risk or good age for reproduction. PRM events can occur both at the age of low risk and high risk. The results of the statistical tests showed no significant effect between the age of the mother giving birth to the incidence of PRM in RSUD Dr. Soegiri Lamongan where from the results of the statistical test results obtained the value of $\mathrm{P}=0.445>0.05$ then $\mathrm{H} 0$ is accepted. While the age of maternity based on OR values obtained results of 1.141 means that the age between 20-35 tends to be PRM at 1.141 times.

The results of the study are in accordance with the research conducted by Fetrisia, W, et al Fetrisia and Nurhasanah (2013) that there was no significant relationship between the age of the mother giving birth and the incidence of PRM where the results of $p=0.542$ were obtained. Research conducted by Nihal, Al Riyami, et al Riyami et al. (2013) also stated that there was no significant relationship between the age of the mother during childbirth and the incidence of PRM before 37 weeks' gestation.

The results of these studies are not in accordance with the theory that the age for optimal reproduction for a mother is between the ages of 20-35 years. In the period of healthy reproduction it is known that the age is safe for pregnancy and childbirth is 20-30 years Wiknjosastro (2014).

\section{Relationship between Parity and PRM}

Based on the results of the study, maternal parity in both the case group and the control group were mostly $(57.5 \%)$ and $(58.2 \%)$ were multiparous parity. The results of statistical tests showed no significant effect between maternal parity and the incidence of PRM in the RSUD Dr. Soegiri Lamongan where from the results of the statistical test the results of the $p$ value $=0.753>$ 0.05 . The parity of the maternity is based on the OR value obtained by 0.933 , which means that maternal parity tends to occur in the PRM to 0.933 times.

The study was in accordance with the research conducted by Nihal, Al Riyami, et al Riyami et al. (2013) that maternal parity had no significant relationship to the occurrence of PRM which occurred at $<37$ weeks' gestation. Research conducted by Fetrisia, W, et al. Fetrisia and Nurhasanah (2013) also stated that there was no relationship between maternal parity and the incidence of premature rupture of membranes with a value of $p=0.824$.

This research is not in accordance with Manuaba's theory Manuaba (2012) which states that multipara parity and grandemultipara are more at risk for premature rupture of membranes. Women who have given birth several times and have had PRM in previous pregnancies as well as the distance of births that are too close are believed to be more at risk of developing PRM in subsequent pregnancies $\mathrm{H}$ (2008).

Based on the results of this study, it can be assumed that maternity with multi parity is not a major risk factor for the occurrence of PRM in RSUD dr. soegiri Lamongan.

\section{Relationship to Fetal Abnormalities with PRM.}

Data for fetal presentation in both the case group and the control group were almost entirely $(87.3 \%)$ and $(95.5 \%)$ were back head presentations. The results of the statistical tests show that there is a significant influence between fetal presentation and the incidence of PRM in RSUD $\mathrm{dr}$. Soegiri Lamongan where from the results of the statistical test results obtained the value of $p$ $=0.045<0.05$. While the number of fetuses based on OR values obtained a result of 2.779 means 
that presentation abnormalities tend to occur 2,779 times the PRM.

The results of these studies are in accordance with the theory that mothers giving birth with presentation abnormalities are very susceptible to the incidence of premature rupture of membranes. Presentation abnormalities cause the lowest part of the fetus to cover or hold the pelvis, and reduce pressure on the lower membrane and the lowest part of the direct amniotic fluid receives dominant intrauterine pressure so that it can cause premature rupture of the membranes Nugroho (2012). According to Fraser Fraser and Cooper (2009), that a pregnant woman who experiences a fetal abnormality causes the surface of the uterus to be uneven with the lowest presentation at the top of the pelvis. This condition causes excessive stretching of the uterus which makes it possible to urge the membranes to rupture before labor begins.

The results of this study are in accordance with the research conducted by Ridwan, $M$, et al $M$ and Herlina (2014) that from statistical tests it was found that there was a relationship between fetal presentation abnormalities with premature rupture of membranes $(\mathrm{p}$ value $=0.005)$ and OR values of 3.5 means mothers with abnormalities the location of the fetus has a 3-fold risk of premature rupture of the membranes during labor compared to mothers who do not experience presentation abnormalities. The results of Ravika's research, R (2013) also stated that there was a relationship between fetal abnormalities and the incidence of PRM in maternity with a value of $\mathrm{p}=0.025$ and $\mathrm{OR}=2.442$ meaning that mothers experiencing fetal abnormalities at risk would be 2.4 times more likely to experience premature rupture of membranes.

\section{Relationship between Twins and PRM.}

Data for the total number of fetuses in the case group was almost entirely (98.5\%) were single pregnancies, whereas in the control group as a whole (100\%) was a single pregnancy. The results of the statistical tests showed no significant effect between the number of fetuses and the incidence of PRM in the RSUD dr. Soegiri Lamongan where from the results of the statistical test results obtained $\mathrm{p}$ value $=0.999>0.05$. While the number of fetuses is based on OR values obtained by the results of 1.394 means that twins have a risk of PRM 1,394 times.

The results of this study are consistent with the research conducted by Fetrisia, W, et al. Fetrisia and Nurhasanah (2013) with Chi Square test results obtained p value $=0.367$ which can be concluded that there is no significant relationship between gemeli (multiple pregnancy) and the incidence of PRM at Achmad Mochtar Bukittinggi Hospital in 2013. While the OR value $=0.245$, which means that gemeli does not significantly affect the incidence of premature rupture of membranes.

The results of this study are not in accordance with the theory which states that one of the causes of premature rupture of the membranes is excessive uterine tension such as multiple / twin pregnancies. Multiple pregnancies will increase intrauterine pressure, with this excessive pressure vascularization does not go smoothly which can cause the membranes to lack connective tissue. So that causes the membranes are not strong or weak and if there is only a slight opening of the cervix the membranes will easily break Manuaba (2012).

\section{Cephalopelvic Disproportion relationship with PRM.}

Data for the incidence of cephalo pelvic disproportion (CPD) in both the case group and the control group were almost entirely (83.6\%) and (97\%) were not experiencing CPD. The results of the statistical test showed that there was a significant influence between CPD on maternity and the incidence of PRM in the RSUD dr. Soegiri Lamongan where from the results of the statistical test results obtained a value of $p=0.002<0.05$. Whereas CPD on maternity is based on OR values obtained by results of 6.201, meaning CPD has a risk of PRM 6,201 times. CPD is a risk factor for the occurrence of premature rupture of membranes, because with mothers who experience CPD can cause abnormalities in the fetus.

The results of this study are in accordance with the theory that maternity with cephalo pelvic disproportion is at risk for premature rupture of membranes. CPD is a condition that arises because there is no balance between the mother's pelvis and the fetus's head caused by a narrow pelvis, a large fetus that cannot pass through the pelvis or a combination of both. In the narrow pelvis there is a possibility that the head is held up by the pelvis, so that the force generated by uterine contractions directly presses on the part of the membranes covering the cervix. As a result the membranes can rupture at the opening is still small Cunningham et al. (2013). According to Oxorn Oxorn (2010), if the pelvis is narrow, the upper pelvis is not completely 
closed by the fetus, the membranes can rupture at a small opening. When the head is held at the top of the pelvis, all the energy from the uterus is directed to the part of the membrane, resulting in premature rupture of the membranes.

This study is not in accordance with the results of a study conducted by Arsiana, et al. Arsiana and Maridti (2012) that there was no significant relationship between CPD and the incidence of PRM in Room C1 of RSUD Dr. M. Yunus Bengkulu with OR value $=0.387$ (95\% CI: 0.073-2,047), meaning statistically is prospective for CPD mothers and not CPD with no difference in PRM.

Large Baby Relations with PRM. Data for the weight of babies born both in the case group and the control group were mostly (59.7\%) and (69.4\%) were normal body weight between 2500 grams - 4000 grams. The results of the statistical tests showed no significant effect between baby weight infants with the incidence of PRM in RSUD dr. Soegiri Lamongan where from the results of the statistical test the results of $p=0.783>0.05$. Whereas $B B$ babies based on OR values obtained a result of 1.057 means that large babies have a risk of PRM 1,057 times.

This study is not in accordance with the theory that macrosomia (large baby) is a baby with birth weight $>4000$ grams will cause distention of the uterus which increases or over distension so that it can cause premature rupture of the membranes. In addition, it can cause intrauterine pressure to increase so that it suppresses the membranes, causing the membranes to become stretched, thin and the strength of the membrane to be reduced, causing an easily ruptured amniotic membrane Oxorn (2010).

\section{CLOSING}

\section{Conclusion}

1. There is a significant relationship between fetal and CPD presentation on the incidence of PRM in maternity and there is no significant relationshiop between maternal age, parity, multiple pregnancies, and infant weight on the incidence of PRM in maternity at RSUD dr. Soegiri Lamongan.

2. Maternal age 1.141 which means that mothers aged 20-35 years have a risk of 1,141 times greater occurrence of PRM.

3. OR parity of 0.933 maternity means mother with multiparous and grande multipara parity has a risk of 0.933 times greater experience of PRM.

4. OR abnormality presentation 2,779 means that women with presentation abnormalities have a risk of 2,779 times greater experience of PRM.

5. OR twin babies 1,394 means mothers giving birth with multiple pregnancies have a risk of 1,394 greater experience of PRM.

6. OR CPD 6,201 means that mothers with CPD have a greater risk of 6,201 experiencing PRM.

7. OR Large infant (macrosomia) 0.783 means that mothers giving birth to large babies (macrosomia) have a risk of 0.783 greater experience of PRM.

\section{Suggestion}

1. For health workers must be more active in providing health education about signs of labor and danger signs of labor to the mother during pregnancy and recommend to pregnant women to immediately go to health workers if there is already felt vaginal discharge or rupture of the membranes.

2. Educational institutions are expected to provide learning to students about PRM so that students can provide midwifery care properly and correctly. 


\section{REFERENCES}

Arsiana, D. and Maridti, Y. (2012). Relationship between CPD and the incidence of PRM in RSUD DR.M. Yunus Bengkulu 5, 101-205.

Budi, R. and Sari, A. N. (2017). Descriptive Study of the Causes of Premature Rupture of Membranes (PRM) in Maternity. Indonesian Journalists and Midwifery 5, 134138.

Cunningham, G. F., Gant, N. F., Leveno, Kenneth, J., III, L. C. G., Hauth, J. C., et al. (2013). Obstetrics Williams (Jakarta: EGC).

Fetrisia, W. and Nurhasanah, S. (2013). Factors Associated with the Events of KPD in Dr Hospital Achmad Mochtar Bukit Tinggi. Journal Kesehatan 4, 72-79. Published 12 Januari 2013.

Fraser, D. M. and Cooper, M. A. (2009). Myles Midwife Textbook (Jakarta: EGC)

H, V. (2008). Midwifery Care Books 4Th Ed (Jakarta: EGC).

M, R. and Herlina (2014). Relationship Between Double Pregnancy and Fetal Disorder with Premature Rupture of Membranes in Demang Sepulau Raya Hospital Central Lampung. Metro SaiWawai Health Journal VII, 43-49. Edisi December 2014.

Manuaba (2012). Midwifery, Gynecology \& Family Planning (Jakarta: EGC).

Marni (2011). Midwifery Pathology Care (Yogyakarta: Student Library).

Ne, A., H, B., F, G., K, B., Y2, B., G, G., et al. (1929). Risk Factors Of Premature Rupture Of Membranes In Public Hospitals At Makele City, Tigray, a Case Control Study. BMC Pregnancy Childbirth 18. doi: 10.1186/SI2884-01. Published 29 September 2018.

Nugroho (2012). Midwifery Pathology (Yogyakarta: Nuha Medika)

of Indonesia Ministry of Health, R. (2017). Indonesian Health Profile in 2016. https://www.kemkes.go.id/
resources/download/pusdatin/lain-lain/Data\%20dan\% 20Informasi\%20Kesehatan\%20Profil\%20Kesehatan\% 20Indonesia\%202016\%20-\%20\%20smaller\%20size\%20\%20web.pdf.

Office, E. J. P. H. (2017). Health Profile of East Java Province in 2016. Health Minister. https://docplayer.info/30225890Profil-kesehatan-provinsi-jawa-timur.html. (Accessed on Accessed 06-10-2018).

Office, L. D. H. (2016). The 2016 Lamongan District Health Profile. (Accessed on Accessed on 06-10-2018).

Oxorn, H. (2010). Midwifery Pathology \& Physiology of Labor (Jakarta: EGC).

Riyami, N. A., Al-Ruheili, I., Al-Shezawi, F., and Al-Khabori, M. (2013). Extreme Preterm Premature Rupture of Membranes : Risk Factors and Feto Maternal Outcomes. Oman Medical Journal 28, 108-111. doi: 10.5001/omj.2013.28.

Wiknjosastro (2014). Midwifery Science, and others (ed.) (Jakarta: Bina Pustaka Foundation Sarwono Prawirohardjo).

Conflict of Interest Statement: The authors declare that the research was conducted in the absence of any commercial or financial relationships that could be construed as a potential conflict of interest.

Copyright (c) 2020 Turlina, and. This is an open-access article distributed under the terms of the Creative Commons Attribution License (CC BY). The use, distribution or reproduction in other forums is permitted, provided the original author(s) and the copyright owner(s) are credited and that the original publication in this journal is cited, in accordance with accepted academic practice. No use, distribution or reproduction is permitted which does not comply with these terms. 